\title{
Chapter 7 \\ Implementation of National Approaches \\ to Circular Migration: Work \\ Authorisation, Residence Status, and Social \\ Security Coordination for Migrant \\ Workers in Bulgaria and Poland
}

This chapter aims to assess the implementation of national and EU legal migration instruments conducive to circular migration against the study's benchmarks in the areas of work authorisation, residence status, and social security coordination which are key policy areas that need to be considered if this type of migration is to be facilitated. Each section commences with a legal and policy analysis of these instruments as of mid-2019 and then moves on to reveal their implementation dynamics. The implementation analysis is based on data retrieved from the Bulgarian and Polish administrations, focus groups with Ukrainian and Russian migrant workers, and interviews conducted with relevant stakeholders as part of the study as well as available data from recent studies. The chapter concludes with an assessment of the developed instruments against the study's benchmarks in these three policy areas, looking inter alia into the possibility for migrants to change employer and occupation, access prolonged status, and export their pensions.

\subsection{Work Authorisation}

Migrant workers' initial work permits very often bind them to a specific employer, sector, and region for a specified period during which they cannot be changed something that can lead to abuse and exploitation. Therefore, the benchmarks in this policy field aim at assessing whether workers can change their employer with a maximum restriction of 2 years. ${ }^{1}$ In addition, they examine whether loss or termination of employment constitutes a sole ground for withdrawal of a migrant worker's

\footnotetext{
${ }^{1}$ Based on Article 14 (a) of Convention concerning Migrations in Abusive Conditions and the Promotion of Equality of Opportunity and Treatment of Migrant Workers, C143, adopted at 60th ILC session on 24 June 1975, Geneva, entry into force on 09 December 1978 (ILO Convention No. 143); and Article 52 (3a) of the International Convention on the Protection of the Rights of All 
authorisation of residence or work permit. ${ }^{2}$ Finally, the benchmarks evaluate the possibility for migrant workers to find alternative work in case of loss or termination of employment ${ }^{3}$ and the possibility for seasonal workers to take up other remunerated activities in cases where they have already been employed on the territory of the Member Sate for a significant period of time. ${ }^{4}$ Flexible work permits allowing change of employer within the period of their validity are among the instruments that can support the implementation of these benchmarks.

\subsubsection{Work Authorisation Conditions According to National Instruments in Poland and Bulgaria}

According to the Polish Act of 20 April 2004 on Employment Promotion and Labour Market Institutions (AEPLMI), ${ }^{5}$ migrant workers can perform work under an employer's declaration of commissioning work to a foreigner (referred to as the Oświadczenie procedure) during a period not exceeding 6 months within the subsequent 12 months in total 'regardless of the number of entities commissioning the work' to foreigners (Article $88 \mathrm{z}$ (2) 3 of the AEPLMI). The main requirement is that 'the Local Labour Office entered the declaration of commissioning work to the foreigner into the register of declarations before commencing work, and that the work is performed under the conditions set out in that declaration' ${ }^{6}$

Even though the Act of 20 April 2004 on Employment Promotion and Labour Market Institutions does not provide for a change of employer, foreigners can register a number of declarations, allowing them to work for several employers simultaneously. This was a documented practice while the procedure was stipulated in a Ministerial regulation until early $2018^{7}$ and used by migrant workers to avoid unemployment. Generally, unemployment would lead to violation of the work visa conditions under the Oświadczenie procedure, which since 2018 has been monitored through a new Central Registration Database established by the amendments to this procedure.

Furthermore, migrant workers who have worked legally for the same employer for more than 3 months under a registered declaration can apply for a work permit (through their employer) or a single permit without having to leave the territory of

\footnotetext{
Migrant Workers and Members of Their Families (ICRMW), G.A. res. 45/158, 18 December 1990, entered into force on 1 July 2003. See Vankova (2016), pp. 342-343 for more details.

${ }^{2}$ Based on Article 8 (1) ILO Convention No. 143 and Article 49 (2) ICRMW.

${ }^{3}$ Based on Article 8 (2) ILO Convention No. 143 and Article 49 (3) ICRMW.

${ }^{4}$ Based on Article 59 (2) ICRMW; Vankova (2016), p. 343.

${ }^{5}$ Ustawa o promocji zatrudnienia i instytucjach rynku pracy (Dziennik Ustaw z 2019 r., poz. 1482, consolidated text).

${ }^{6}$ Article 87 (3) AEPLMI.

${ }^{7}$ Interview \#1 with officials, Poland, November 2016, Annex II. Interview \#12 with civil society actor, Poland, November 2016, Annex II.
} 
the country. This possibility is stipulated in Article 88za of the AEPLMI. A labour market test is not required in instances where a foreigner has worked for the same employer for more than 3 months and has worked in the same position throughout the duration of the Oświadczenie procedure directly before applying for a work permit. ${ }^{8}$ In order to benefit from this exemption, the foreigner must present the registered declaration to the Local Labour Office along with a labour contract and documentation evidencing the payment of social security contributions. ${ }^{9}$ Another exemption in this regard concerns nationals from the countries covered by the Oświadczenie procedure who provide care and nursing services or who are household staff for natural persons in a household.

Since foreigners who have obtained the Karta Polaka are entitled to take up employment in the territory of Poland without needing to apply for a work permit ${ }^{10}$ and can conduct economic activity on the same conditions as those applicable to Polish citizens, ${ }^{11}$ they do not face any restrictions regarding change of employer or occupation. In addition, the only restriction is the validity of their visas but they have facilitated access to residence permits, which additionally mitigate the potential challenges they might face. All this means that there are no consequences if they lose their jobs.

In comparison, Article 7 (2) of the Bulgarian Act on Labour Migration and Labour Mobility (ALMLM) ${ }^{12}$ stipulates that workers who are third-country nationals and who have been granted labour market access can be employed only by a natural or legal person in a place, at a position, and for a duration matching those specified in the work authorisation. The right to access the labour market can be withdrawn if the General Labour Inspectorate establishes that the third-country national's employment does not match the one specified in the work authorisation in line with Article 7 (3) (Article 12 (1) 2 of the ALMLM). The Act does not contain a general provision for the possibility of accessing all types of employment and change of occupations subject to a maximum restriction, apart from the options derived from the specific permits based on the EU legal migration directives and the permanent residence status.

Upon the premature termination of an employment relationship with a thirdcountry national, the employer is obliged to notify the Bulgarian Employment

\footnotetext{
${ }^{8}$ Para 3 (3) of Regulation of the Minister of Labour and Social Policy of 29 January 2009 on determining cases in which a work permit for a foreigner is issued irrespective of the detailed conditions for issuing work permit for foreigners/Rozporządzenie Ministra Pracy i Polityki Społecznej z dnia 29 stycznia 2009 r. w sprawie określenia przypadków, w których zezwolenie na pracę cudzoziemca jest wydawane bez względu na szczegółowe warunki wydawania zezwoleń na pracę cudzoziemców (Dziennik Ustaw z 2019 r., poz. 154).

${ }^{9}$ Ibid., Para 3 (2). When the foreigner will be employed on the basis of the so-called civil contract, they cannot make use of this provision.

${ }^{10}$ See Article 87(2) 6 AEPLMI.

${ }^{11}$ European Migration Network (2012), p. 21.

12 Закон за трудовата миграция и трудовата мобилност (SG No 33/26 April 2016, last amendment No 34/23 April 2019).
} 
Agency in writing within 3 days from the date of termination of the employment (Article 10 (4) of the ALMLM). In such cases, an application for a new labour market access authorisation can be submitted after a 3-month interruption between the expiry of a third-country national's permit or the premature termination and the request for a new starting period of employment (Article 7 (1) 1 and 2 of the Implementing Regulation of the $\mathrm{ALMLM}^{13}$ ). Nevertheless, migrants who are exempted from the requirement to apply for a work permit - such as foreigners of Bulgarian origin - do not face challenges concerning change of employer or occupation.

In addition, a look at the bilateral labour migration instruments concluded shows that Article 3 of the Agreements, respectively, between Bulgaria and Armenia ${ }^{14}$ and Bulgaria and Moldova ${ }^{15}$ stipulate that the entry, residence, and employment of nationals of the contracting parties on the territory of the other state shall be governed by the legislation of the receiving state. Since there is no explicit provision related to the change of employer and the possibility to find alternative employment, these are subject to the national law of the contracting parties.

\subsubsection{Implementation Dynamics}

The interviewed migrants and NGO representatives in Poland did not report any problems concerning their change of employer or any unemployment they faced during the authorised period under the Oświadczenie procedure. However, two other problematic issues relating to the implementation of the Oświadczenie procedure were identified during the fieldwork at the end of 2016. The first was the fact that the procedure was regulated by a Ministerial regulation and not by the general normative act on employment. The Ministry of Family, Labour and Social Policy issued interpretative guidelines on the application of the Oświadczenie procedure,

\footnotetext{
${ }^{13}$ Правилник за прилагане на Закона за трудовата трудовата миграция и трудовата мобилност (SG No. 79/ 7 October 2016, last amendment SG No. 27/ 2 April 2019).

${ }^{14}$ Agreement between the Republic of Bulgaria and the Republic of Armenia on labour migration management, approved by Council of Ministers Decision No. 176 of 22 March 2018, entered into force 9 October 2018/Спогодба между Република България и Република Армения за регулиране на трудовата миграция, утвърдена с Решение № 176 от 22 март 2018 г. на Министерския съвет. В сила от 9 октомври 2018 г.

${ }^{15}$ Agreement between the Government of the Republic of Bulgaria and the Government of the Republic of Moldova on labour migration management, approved by Council of Ministers Decision No 492 of 13 July 2018, entered into force on 11 September 2018/Спогодба между правителството на Република България и правителството на Република Молдова за регулиране на трудовата миграция, утвърдена с Решение № 492 на Министерския съвет от 13 юли 2018 г. В сила от 11 септември 2018 г.
} 
which were in practice a non-legally binding set of recommendations. ${ }^{16}$ On the basis of these interpretive guidelines, the Local Labour Offices were using their discretion to apply or issue their own interpretation of the Regulation that in some of the cases differed so much that it was compared to the 'invention' of new legislation. ${ }^{17}$ The Local Labour Office in Warsaw, for example, introduced restrictions that were not provided in the Regulation, such as a cap on the number of Oświadczenie that one employer could obtain and a requirement that the company should have been in operation for at least 1 year. This wide discretion was limited through the amendments in $2018^{18}$ but these did not explicitly stipulate any provisions on change of employer and sector, which continues to be a persisting problem that naturally creates legal uncertainty for the migrant workers.

The second major problem with the implementation of the Oświadczenie procedure was the widespread abuse of migrant workers because they often worked irregularly. In the sectors of agriculture, construction, and domestic services it was the case that even Polish nationals were working irregularly because it was too expensive to legally employ workers due to the high financial burden stemming from taxation and social security obligations, and due to onerous bureaucratic hurdles. ${ }^{19}$ An interviewee said that it was common for employers to abuse Ukrainian workers by not paying their last salary as they knew that their work visa was expiring and would therefore have to leave the country. ${ }^{20}$ But even more severe cases of exploitation were recorded. For example, several Ukrainian workers were forced to work in a cigarette factory without being given their wages; their passports were taken from them and they were promised payment only at the end of their stay in Poland. ${ }^{21}$

According to one of the interviewed NGO representatives, the Ukrainian circular migration pattern was always based on legal entry into Poland and irregular work. ${ }^{22}$ Before Poland's accession to the Schengen area in 2017, Ukrainians did not need a visa to enter Poland. Once Poland introduced visas, the state had to invent another special instrument to allow people to enter and work by introducing new grounds for issuing a visa. The fact that this instrument was functioning for more than 10 years, and given that before the 2018 reforms there had been no political will to change it, meant that 'we are really eager to see immigrants from Ukraine working illegally in Poland because it's cheaper, it's better for Polish economy, it's better for Polish employers and it's very convenient not to interfere in this interaction, not to

\footnotetext{
${ }^{16}$ Interview \#1 with officials, Poland, November 2016, Annex II. The guidelines contained mainly issues to be verified and the possibility to refuse registration. Interview \#1 with officials, Poland, November 2016, Annex II.

${ }^{17}$ Interview \#12 with civil society actor, Poland, November 2016, Annex II.

${ }^{18}$ See Chapter 5, section 5.2.1.1 for more details.

${ }^{19}$ Interview \#5 with civil society actor, Poland, November 2016, Annex II. Interview \#12 with civil society actor, Poland, November 2016, Annex II.

${ }^{20}$ Interview \#11 with trade union representative, Poland, November 2016, Annex II.

${ }^{21}$ Interview \#11 with trade union representative, Poland, November 2016, Annex II.

${ }^{22}$ Interview \#12 with civil society actor, Poland, November 2016, Annex II.
} 
assist any migrants because otherwise we could be seen as country who exploits immigrants'. ${ }^{23}$ The latest research shows that migrants using the assistance of an employment agency are usually hired on the basis of a civil law contract (umowa zlecenie). ${ }^{24}$ However, this prevents such workers from benefiting from the Labour Code protection.

By way of comparison, according to one of the interviewed Bulgarian lawyers, the labour market test makes migrants dependent on employers and is conducive to corruption, as already described in Chap. $6{ }^{25}$ This is due to the fact that changing an employer means repeating the whole application process, including the labour market test, for most categories of workers. As one interviewee stressed: 'This practically leads to a legal bondage to a certain employer in 21 st century. This is pure feudalism'. ${ }^{26}$ The interviewed officials confirmed that in the majority of cases, if workers wanted to change their employer, they needed to leave the country and then re-apply after the above-mentioned interruption. ${ }^{27}$

The participants in the focus groups did not mention any problems in relation to changing employers because most of them stayed in Bulgaria on trade representation grounds and worked for their own companies. One of the participants in the Russian focus groups said that she had hoped to be able to apply for a Blue Card, but when she understood that the Directive was (initially) transposed in such a way that would only allow her to apply from outside the country, she decided that this would be too risky because she only had 2 years left until she would be eligible for an EU long-term residence permit. ${ }^{28}$

\subsubsection{Work Authorisation Conditions and Implementation Dynamics According to the Legal Migration Directives Aiming to Facilitate Circular Migration}

\subsubsection{Blue Card Directive ${ }^{29}$}

Article 133 (2) of the Polish Act on Foreigners transposed Article 13 of the Blue Card Directive, allowing Blue Card holders to retain their permits in case of unemployment for a period of 3 months within the validity of the permit. However, the period in which the foreigners remain unemployed can only occur a maximum of

\footnotetext{
${ }^{23}$ Interview \#12 with civil society actor, Poland, November 2016, Annex II. Interview \#11 with trade union representative, Poland, November 2016, Annex II.

${ }^{24}$ Pawlak and Lashchuk (forthcoming).

${ }^{25}$ Interview \#9 with lawyer, Bulgaria, July 2016, Annex III. For more details, see Chap. 6, Sect. 6.2.

${ }^{26}$ Interview \#9 with lawyer, Bulgaria, July 2016, Annex III.

${ }^{27}$ Interview \#10 with officials, Bulgaria, July 2016, Annex III.

${ }^{28}$ Focus group with Blue Card holders from Russia, Bulgaria, September 2016, Annex IV.

${ }^{29}$ Council Directive 2009/50/EC of 25 May 2009 on the conditions of entry and residence of thirdcountry nationals for the purposes of highly qualified employment [2009] OJ L 155/17.
} 
twice and for no longer than a combined duration of 3 months ${ }^{30}$ within the period of the permit's validity ${ }^{31}$ To benefit from this exception, the foreigners need to notify the competent regional governor (voivode) within 15 working days that they have lost their job. ${ }^{32}$

In the event that Blue Card holders in Bulgaria become unemployed, they are entitled to a period of 3 months to look for new employment and start working in line with the initial application procedure (Article 21 (1) of the ALMLM). The Employment Agency cannot propose the Blue Card permit's withdrawal within this period (Article 21 (3) of the ALMLM). By contrast to the Polish case, the right to look for a new employer can only be used once within the period of validity of the Blue Card (Article 21 (4) of the ALMLM).

During the first 2 years of their stay in Poland on the basis of a Blue Card permit, foreigners cannot change their employer or the position for which they are employed and they cannot receive a lower salary than the one specified in the permit without an amendment to the permit by the competent governor. ${ }^{33}$ In line with Article 135 (1) of the Act on Foreigners, the permit can be amended by the governor at any time. After the first 2 years, foreigners are only required to inform the governor about any changes concerning position, remuneration, and other conditions specified in the permit. $^{34}$

Likewise, in line with the Directive, during the first 2 years of their employment, Blue Card holders in Bulgaria may only change their employer after obtaining a written positive decision that has been issued by the Employment Agency (Article 20 (2) of the ALMLM). The procedure for granting the abovementioned decision is carried out in line with the criteria contained in Article 15, which outlines the initial Blue Card application process (Article 18 of the Implementing Regulation of the ALMLM). After the initial period of 2 years, in order to change employer, Blue Card holders need to restart the application process for the permit in line with Article 17 of the ALMLM (Article 20 (3) of the ALMLM).

\subsubsection{Blue Card Directive - Implementation Dynamics}

According to the migrants interviewed in Poland, one of the major advantages of this permit was that it gave them the right to change employer and be unemployed for up to 3 months. ${ }^{35}$ Most of the focus group participants knew that single permit holders could not benefit from these favourable conditions and needed to restart the whole process if they wanted to change employer. Nonetheless, the Blue Card

\footnotetext{
${ }^{30}$ Unterschütz, (2016), p. 186.

${ }^{31}$ Article 133 (2) 2 AF.

${ }^{32}$ Article 134 (1) AF.

${ }^{33}$ Article 135 (2) AF.

${ }^{34}$ Unterschütz (2016), p. 186. See Article 134 (3) AF.

${ }^{35}$ Focus groups with Blue Card holders: mixed group of Russian speakers, Russians and Ukrainians,

Poland, December 2016, Annex IV.
} 
holders interviewed emphasised that outside their company, which provided a relocation manager to support them in the application process, their colleagues who wished to change employer had to conduct the procedure themselves and faced bureaucratic hurdles and long queues, while some had to switch to a single permit and restart the whole procedure. ${ }^{36}$

Another problem shared by the focus group participants from Ukraine was that changes in the permit concerning employment conditions (position, salary, another contract) with the same employer had to be notified to the governor and that the changes allowed were capped. They even gave an example of a colleague who was promoted and declined the position because he did not want to start the procedure all over again as 'there is no guarantee the second time it will also be a Blue Card'. The interviewed IT company management representatives confirmed that this requirement 'in terms of flexibility, it is a blocker' ${ }^{37}$ Therefore, they used some 'loopholes' in the legislation because if they followed it strictly, they would not have been able to change position within the company.

Most of the Blue Card holders who participated in the focus groups had arrived relatively recently in Bulgaria and their main problems related to the application process, the renewal of their permits, and family reunification. None indicated any plans to change employer.

\subsubsection{Seasonal Workers' Directive ${ }^{38}$}

In line with Article 15 (3) of the Directive, when a foreigner has entered Poland on a visa issued for the purpose of seasonal work or as part of a visa-free regime in connection with an application for a seasonal work permit, ${ }^{39}$ the local governor may extend the seasonal work permit for the same entity entrusting work to the foreigner or to perform seasonal work for another entity entrusting the work to the foreigner (Article 88u (1) of the AEPLMI). To extend the seasonal work permit, the provisions regarding the issue of the seasonal work permit apply accordingly (Article 88v of the AEPLMI). This means that the application needs to be registered and the employer has to present to the competent local governor a copy of a valid document entitling the foreigner to stay in Poland along with the foreigner's accommodation address during their stay in the country (Article 88p (7) of the AEPLMI). The extension of the seasonal work permit is issued for a period which, together with the period of stay of the foreigner for the purpose of performing seasonal work counted from the day of first entry into the territory of the Schengen States in a given calendar year - is not longer than 9 months during the calendar year (Article

\footnotetext{
${ }^{36}$ Focus group with Blue Card holders from Ukraine, Poland, December 2016, Annex IV.

${ }^{37}$ Interview \#22 with IT business management representatives, Poland, December 2016, Annex II.

${ }^{38}$ Directive 2014/36/EU of the European Parliament and of the Council of 26 February 2014 on the conditions of entry and stay of third-country nationals for the purpose of employment as seasonal workers [2014] OJ L 94.

${ }^{39}$ Entered in the register referenced in Article 88p (1) 1 AEPLMI.
} 
88u (3) of the AEPLMI). The Act does not limit the number of applications for extension nor does it require performance of a labour market test as part of the permit extension procedure.

A permit is extended at the written request of the employer, submitted no earlier than within 90 days and no later than within 30 days before the expiry of the permit's validity (Article 88a (1a) of the AEPLMI). If an employer has applied for an extension of a foreigner's seasonal work permit and the application does not contain formal deficiencies or formal deficiencies have been removed on time, the work of the foreigner under the conditions set out in the permit for seasonal work is considered legal from the date of the application's submission to the day on which the decision to extend the seasonal work permit becomes final ${ }^{40}$ (Article $88 \mathrm{u}$ (4) of the AEPLMI). If the application for the extension of the seasonal work permit was submitted by a different employer, the work of that foreigner under the conditions specified in the application are considered legal until the date of the local governor's decision, but not longer than for a period of 30 days from the date of submission of the application that does not contain formal deficiencies (Article 88u (5) of the AEPLMI). The only way to avoid withdrawal of the seasonal worker permit under Article $88 \mathrm{y}$ of the AEPLMI in case of unemployment is for the worker to secure another job with a different employer before the expiry of the permit's validity since the Act does not explicitly allow for seasonal workers to look for another job within a reasonable time. ${ }^{41}$

Concerning the benchmark on change of occupation, seasonal workers are entitled to work only in the fields of agriculture, forestry, fishery, services, gastronomy, and hospitality (concerning short stays and high seasons) in line with Regulation of the Minister of Family, Labour and Social Policy of 8 December 2018. ${ }^{42}$ The Act does not limit the possibility of changing seasonal occupations when a different employer applies for an extension of the seasonal work permit as long as the new seasonal occupation is specified in the work permit application and respective contract in line with Article 88a (1aa) of the AEPLMI. The only category of foreigners who have the possibility of performing work outside the list of seasonal occupations determined by the above-mentioned Regulation are the citizens of Armenia, Belarus, Georgia, Moldova, Russia, and Ukraine. They can do so for a period not longer than a total of 30 days during the validity of their permits and given that their remuneration is not lower than the one specified in their permit and that they do not work as temporary employees (Article $88 \mathrm{~s}$ (1) of the AEPLMI).

\footnotetext{
${ }^{40}$ The periods of legal work do not include periods of suspension of proceedings at the request of a party.

${ }^{41}$ See Chap. 4, Sect. 4.3 for more details.

${ }^{42}$ Regulation of the Minister of Family, Labor and Social Policy of 8 December 2018 regarding activity subclasses according to the Polish Classification of Activities (PKD), in which seasonal work permits for a foreigner are issued/Rozporządzenie Ministra Rodziny, Pracy i Polityki Społecznej z dnia 7 września 2018 r. zmieniające rozporządzenie w sprawie podklas działalności według Polskiej Klasyfikacji Działalności (PKD), w których wydawane są zezwolenia na pracę sezonową cudzoziemca (Dziennik Ustaw z 2018 r., poz. 1749).
} 
According to the Bulgarian Act on Foreigners, the permit for a seasonal worker can be extended once within the respective authorised period of stay - not less than 90 days and not more than 9 months - upon a decision by the Employment Agency (Article 24к (2) of the AFRB). This provision allows seasonal workers to extend their permit with their current employer or renew it by changing their employer once (Article 29 of the ALMLM). In case they want to change their employer, seasonal workers are not bound by the requirement of Article 5 (2), namely, to reside outside the country when applying for a work permit (Article 29 (1) of the ALMLM). They have the right to continue to reside in Bulgaria until a decision on the application is made, provided that the application was submitted within the period of validity of the permit and the authorised period of stay has not expired (Article $24 \mathrm{k}$ (7) of the AFRB). An opportunity to seek employment in an area other than seasonal work, for which the permit is granted, is not explicitly regulated in the provisions of the ALMLM.

\subsubsection{Seasonal Workers' Directive - Implementation Dynamics}

As mentioned in Chap. $6,{ }^{43}$ the delay in transposing this Directive in Poland and the fact that seasonal workers in Bulgaria were mainly working irregularly in 2016 when the study's focus groups with migrants were conducted did not allow for data collection on the implementation of this instrument. A recent study covering seasonal workers in Bulgaria, ${ }^{44}$ as well as the annual report of Bulgaria's Main Labour Inspectorate, demonstrate that the illegal practice of presenting foreign nationals' seasonal work as internships was restricted, and currently migrant workers are generally employed on the basis of labour contracts. ${ }^{45}$ However, most come for a stay of up to 90 days, which is the most commonly-used entry channel because it is cheaper and less cumbersome for employers. In Poland, at the time of writing, there was still no comprehensive study of the implementation of the Seasonal Workers Directive and this does not allow conclusions to be drawn regarding work authorisation.

\footnotetext{
${ }^{43}$ See Chap. 6, Sect. 6.3.3.4 for more details.

${ }^{44}$ Vankova and Ivanova (forthcoming).

${ }^{45}$ Executive Agency Main Labour Inspectorate (2019), p. 22.
} 


\subsubsection{Work Authorisation Conditions and Implementation Dynamics According to the Legal Migration Directives Containing Circular Migration Elements and Flanking Rights}

\subsubsection{Intra-corporate Transferees' Directive ${ }^{46}$}

ICTs are entitled to perform work in Poland for a particular employer and position under the conditions stipulated in the decision to grant a temporary residence permit and their contract (in line with Articles 139a and 139h of the AF). Therefore, they cannot change their occupation and employer within the period of validity of the ICT permit as this would affect the admission conditions and lead to the permit's withdrawal (Article 139g of the AF). Furthermore, the receiving enterprise has the obligation to notify in writing within 15 working days the regional governor who granted the ICT permit of any change in circumstances affecting the conditions of the permit granted (Article 139m (1) of the AF).

In line with the ICT Directive, the relevant Bulgarian act does not legislate for a change of employer or sector: the ICT permit entitles a third-country national to work in the territory of the Republic of Bulgaria for a specific receiving enterprise or group of enterprises only and solely in the position of manager, specialist, or trainee employee (Article 31 (3) of the ALMLM). Thus, ICTs cannot change their employer and occupation within the period of validity of the ICT permit.

The receiving enterprise is obliged to notify the Bulgarian Employment Agency of any changes in relation to the conditions for granting the permit (Article 31 (4) of the ALMLM). This means that in the case of ICTs, premature termination of their employment relationship with the sending enterprise would lead to a withdrawal of their permit because this would affect the admission conditions stipulated in Article 31 of the ALMLM and Article 23 of its Implementing Regulation. Therefore, if ICT permit holders wish to look for alternative work, they need to exit the country and then apply for another permit in Bulgaria.

\subsubsection{Intra-corporate Transferees' Directive - Implementation Dynamics}

As already demonstrated in Chap. 6, the use of the ICT Directive in practice is marginal in both Bulgaria and Poland. According to the interviewed representatives of a Bulgarian IT company, the procedure developed on the basis of the ICT Directive became much more cumbersome after the adoption of the Implementing

\footnotetext{
${ }^{46}$ Directive 2014/66/EU of the European Parliament and of the Council of 15 May 2014 on the conditions of entry and residence of third-country nationals in the framework of an intra-corporate transfer [2014] OJ L 157.
} 
Regulation of the ALMLM.$^{47}$ According to their perspective, the ICT transfer was likened to a long-term business trip. They remarked that before the adoption of this Implementing Regulation, the procedure provided for the conclusion of a labour contract with the receiving enterprise to which the workers transferred, and that this was the procedure they had followed. Currently, however, the working conditions for third-country workers with an intra-corporate transfer permit are regulated under the terms and conditions for posted or sent workers within the framework of provision of services in the territory of the Republic of Bulgaria (Article 32 (1) of the ALMLM).$^{48}$ The amendments of the procedure also raised questions with regard to the possible renewal of this permit after the expiration of the maximum allowed 3-year period. ${ }^{49}$ This insecurity led the company to prefer making use of the other available instruments, such as the Blue Card and Single Permit Directives.

In Poland, according to a report by Deloitte, the alternative local permits on assignment or local contract basis were considered faster in terms of processing times, as well as easier and cheaper in terms of procedure, thus offering a possible explanation as to why this instrument has not been preferred by Polish business enterprises. ${ }^{50}$

\subsubsection{Students' and Researchers' Directive ${ }^{51}$}

The Polish Act on Foreigners does not legislate for any change of host research institution and the legal consequences for the researcher in case of unemployment, e.g., where the host research institution loses its authorisation. This means that in such cases, if the grounds for issuing the permit are no longer valid in line with Article 154a of the AF, the permit should be withdrawn. In the same vein, Bulgarian migration law does not legislate for the change of hosting organisation for

\footnotetext{
${ }^{47}$ Interview \#20 with representatives of an IT company, Bulgaria, December 2016, Annex III. The interviewees were referring to the amendments made to correct the transposition of the Directive into Bulgarian law.

${ }^{48}$ In accordance with the Bulgarian Labour Code (Кодекс на труда, SG No. 26/1 April 1986, last amendment SG No. 92/ 6 November 2018), the sending of employees within the context of the provision of services occurs, inter alia, when: an undertaking that employs a worker temporarily registered under the legislation of a third country sends a worker to an undertaking in the territory of Bulgaria (Article 121a (2) 2 of the Labour Code). An employee may be posted or sent, where for the entire period of secondment/sending or posting, there is an employment relationship between the latter and the seconding or sending employer, which is one of the conditions for obtaining an ICT permit (Article 121a (3) of the Labour Code and Article 40 (2) 1 of the ALMLM in conjunction with Article 25 (1) 3 of the Implementing Regulation of the ALMLM).

${ }^{49}$ Interview \#20 with representatives of an IT company, Bulgaria, December 2016, Annex III.

${ }^{50}$ Deloitte (2018), p. 42.

${ }^{51}$ Directive (EU) 2016/801 of the European Parliament and of the Council of 11 May 2016 on the conditions of entry and residence of third-country nationals for the purposes of research, studies, training, voluntary service, pupil exchange schemes or educational projects and au pairing [2016] OJ L 132.
} 
researchers. There are no legal provisions regulating cases of unemployment, which means that when the hosting agreement has been terminated, the permit of the researcher would be withdrawn because the circumstances for its granting would have changed (see Article 24 (2) AFRB).

However, it should be stressed that the wording of Article 21 (5) of the Students' and Researchers' Directive implicitly sets out the possibility of changing a host institution by stating that in cases when the researcher applies for a renewal of authorisation to enter into an employment relationship with a host institution and is not continuing the employment relationship with the same host institution, Member States can apply labour market tests in this regard. Therefore, researchers should be able to change their hosting research institution if they have a hosting agreement that meets the requirements of the admission conditions specified in Article 10 of the Students' and Researchers' Directive.

Concerning unemployment, the Students' and Researchers' Directive is silent as to whether unemployment could automatically lead to withdrawal of the residence permit. ${ }^{52}$ Article 10 (5) of the Directive states that the hosting agreement should automatically lapse when the legal relationship between the researcher and the research organisation is terminated. In addition, Article 10 (8) leaves it to the discretion of Member States to regulate in national law consequences for researchers' authorisations as a result of withdrawal of the approval or the refusal to renew the approval of the hosting agreements. Therefore, the Directive does not oppose any national rules that would allow the researchers to look for another research organisation or job. Not allowing for a reasonable period to look for another job would also take away the effet utile of Article 25 of Students' and Researchers' Directive allowing researchers to seek employment or set up a business for a period of at least 9 months after completion of their research.

\subsubsection{Students' and Researchers' Directive - Implementation Dynamics}

Like the ICT Directive, the Recast Students' and Researchers' Directive is only marginally used in Bulgaria and Poland as illustrated in Chap. $6 .{ }^{53}$ The interviewed migrants in Poland who were working as researchers possessed either the Karta Polaka or EU long-term residence and did not report any problems associated with changing employer. This is not surprising given the fact that for the former category there are not any explicit regulations on change of employer nor any restrictions for the latter. The 2014 implementation Plan for the 'Migration Policy of Poland: current state of affairs and proposed actions' envisaged the abolition or reduction of fees for issuing a temporary residence permit for researchers arriving in Poland with the aim of conducting research. ${ }^{54}$ This was due to the fact that many

\footnotetext{
${ }^{52}$ See Article 21 (1) (a) of the SRD.

${ }^{53}$ See Chap. 6, Sect. 6.3.4.4 for more details.

${ }^{54}$ Implementation Plan for the Migration Policy of Poland: current state of affairs and proposed actions/Polityka migracyjna Polski - stan obecny i postulowane działania, p. 30.
} 
researchers preferred to reside in Poland on the basis of a long-term national visa because it was free of charge rather than on temporary residence permit, which had the effect of placing them in a precarious position. This would have had a positive impact on researchers, who would have been required to change their research institution and restart the whole permit application procedure. Nevertheless, as already emphasised, the government repealed this policy in 2016 and it is not yet clear whether there will be any measures in this regard in the future. As demonstrated in Chap. 6, the implementation of the EU acquis concerning researchers in Bulgaria is also not without problems. ${ }^{55}$

\subsubsection{Singe Permit Directive ${ }^{56}$}

According to Article 123 of the Polish Act on Foreigners, the single permit cannot be revoked within 30 days from the date of unemployment if the foreigners notify the competent governor of the loss of the job indicated in the permit. The notification needs to be carried out within 15 days from the loss of the job (Article 121 (1) of the AF). This provision, however, cannot apply more than once during the period of the permit's validity (Article 123 (2) of the AF). Based on this provision, foreigners can change their employer or job if working conditions are unfavourable or if they receive a better job offer elsewhere. Nevertheless, this means that migrant workers need to start a new procedure for obtaining a single permit, which additionally requires the performance of a labour market test in line with Article 125 of the Act on Foreigners.

By contrast, following Bulgaria's 'copy and paste' approach to EU law, the ALMLM is 'harmonised' with the Single Permit Directive and does not contain any explicit rules on changing employers. Furthermore, it does not provide for a period during which the migrant worker can seek alternative employment. What is clear, however, is that any interruption of a worker's employment would be grounds for refusing an extension of the single permit (Article 15 (3) of the ALMLM).

\subsubsection{Singe Permit Directive - Implementation Dynamics}

One of the Russian participants in the focus groups remarked that the introduction of single permits worsened the situation in Poland because 'they bound the employees to their employers' ${ }^{57} \mathrm{He}$ explained that if one wanted to change employer, then one had to restart the whole single permit application procedure from the first step:

\footnotetext{
${ }^{55}$ See Chap. 6, Sect. 6.3.4.4 for more details.

${ }^{56}$ Directive 2011/98/EU of the European Parliament and of the Council of 13 December 2011 on a single application procedure for a single permit for third-country nationals to reside and work in the territory of a Member State and on a common set of rights for third-country workers legally residing in a Member [2011] OJ L 343.

${ }^{57}$ Focus group with Russian migrants, Poland, November 2016, Annex IV.
} 
'but who wants to do that?' The focus group participant also emphasised another impediment: in order to get a work permit for certain professions, one's salary needed to match a set threshold. ${ }^{58}$ Another interviewee stressed that the introduction of the single permit had 'very negative consequences' because once the migrants decided to change their job, their position within the company, the type of contract, or if their salary decreased, then they would have to apply for a new single permit. ${ }^{59}$ The whole process could take up to 1 year from the moment of submission until the moment of receipt, "which is already official information from the Head of the Office of foreigners in Warsaw' ${ }^{60}$ In case the validity of the single permit had expired, migrants from the six eligible countries could work on the basis of the Oświadczenie procedure but had to apply for a visa to do so. ${ }^{61}$ However, after 2014, Ukrainian men working in Poland were generally not willing to return home and re-apply for a visa because they were sent subpoenas as part of the ongoing mobilisation to join the Ukrainian army due to the conflict in Crimea. ${ }^{62}$

An NGO representative shared that the transposition of the Directive itself created a 'traffic jam' in the administration and that 'it works really, really slow, sometimes unpredictable' ${ }^{63}$ One strategy employed by migrants who wanted to change their single permit was to apply for a separate work permit for their second/new job at the very same time as applying for a new single permit to keep their work legal while they were waiting for the single permit to come through. This costed extra money for the applicants: before the introduction of the Single Permit Directive, the procedure costed 340 złoty ( 80 EUR), while at the time of writing the fee was 440 złoty (104 EUR) and the employer had to pay a further 100 złoty (23.50 EUR) to obtain a work permit.

The interviewee also declared that some companies preferred to keep migrant workers out of legal employment during the period before obtaining a work permit because the employee was tied to the company: 'they are quite sure that they won't leave them until they get at least the permit and they will be working without taxes and social security contributions' ${ }^{64}$ Nevertheless, the foreigner was trapped:

\footnotetext{
'because even if he could change the employer while the procedure lasts, he still has to have somebody to employ him, to run the labour market test for him, to resubmit application and also to submit documents saying that he quitted the job because afterwards the procedure can be cancelled' ${ }^{65}$
}

\footnotetext{
${ }^{58}$ The focus group participant was referring to the fact that in order to obtain a work permit, the remuneration specified in the contract with the foreigner could not be lower than the salaries of other employees performing work of comparable type or in a similar position.

${ }^{59}$ Also stressed in Interview \#12 with civil society actor, Poland, November 2016, Annex II and Interview \#5 with civil society actor, Poland, November 2016, Annex II.

${ }^{60}$ Interview \#3 with civil society actor, Poland, November 2016, Annex II.

${ }^{61}$ See Chap. 5, Sect. 5.2.1.1. for more details.

${ }^{62}$ For more info, see Home Office (2016).

${ }^{63}$ Interview \# 3 with civil society actor, Poland, November 2016, Annex II.

${ }^{64}$ Interview \#3 with civil society actor, Poland, November 2016, Annex II.

${ }^{65}$ Interview \#3 with civil society actor, Poland, November 2016, Annex II.
} 
In this period the migrants were not officially unemployed because they were waiting for their new single permit, but they could not officially be employed because one needed to have a visa or a work permit to do so according to the applicable Polish legislation. They were thus working in the informal market without an official contract. According to the interviewed NGO representative, migrants preferred this mechanism rather than returning to their country of origin and waiting there for 4 months without an opportunity to plan anything before the visa was either granted or refused. ${ }^{66}$

In Bulgaria, as described in Chap. 6, most of the migrant workers who participated in the focus groups shared that they have avoided the single permit application due to the cumbersome entry requirements that include performance of a labour market test.

\subsection{Residence Status}

As already stressed in this book, access to permanent residence and circular migration seem at first like two separate and unrelated policy areas. However, 'leakage' into permanent settlement in the host country is an inherent characteristic of circular migration. ${ }^{67}$ Therefore, this study's analytical benchmark framework aims to explore whether lawful migrants have the opportunity to qualify for a prolonged or permanent residence status ${ }^{68}$ on the basis of permits allowing transition from a temporary to a permanent residence status. ${ }^{69}$ In addition, this section considers whether migrants have the right to mobility and a choice of residence within the host country. ${ }^{70}$

\subsubsection{Residence Status According to National Instruments in Poland and Bulgaria}

Migrant workers in Poland who have worked legally for more than 3 months under the Oświadczenie procedure with the same employer under a registered declaration, can apply directly for a work permit or a single permit without having to leave the

\footnotetext{
${ }^{66}$ Interview \#3 with civil society actor, Poland, November 2016, Annex II.

${ }^{67}$ Skeldon (2012), p. 53.

${ }^{68}$ On the basis of Article 2 of the European Convention on Establishment, ETS No. 19, 13 December 1955, entry in force 23 February 1965.

${ }^{69}$ Vankova (2016), p. 344.

${ }^{70} \mathrm{On}$ the basis of Article 12 (1) of the International Covenant on Civil and Political Rights (ICCPR), G.A. res. 2200A (XXI), 16 December 1966, entered into force on 23 March 1976; Article 39 ICRMW; Article 2 (1) of the Fourth protocol to the ECHR, ETS No.046, 16 September 1963, entered into force on 02 May 1968.
} 
country. Both processes provide for an accumulation of residence periods and can lead to permanent residence, depending on the individual cases, either through the national or through the EU long-term residence procedures. Holders of a valid Karta Polaka who plan to settle permanently in the territory of Poland are also eligible to apply for permanent residence in line with Article 195 (1) 9 of the Act on Foreigners. The application is free of charge and after the permit has been granted, the foreigners and their family members can benefit from financial assistance for a period of up to 9 months. ${ }^{71}$

The national permanent residence permit is issued for specific categories of foreigners such as children of foreigners with permanent residence permits or EU long-term resident permits; children or spouses of Polish citizens; foreigners of Polish origin; victims of human trafficking; tolerated residence permit holders; and, persons with granted refugee status or with subsidiary protection and humanitarian statuses. ${ }^{72}$ Depending on the different categories, foreigners can also be required to have stayed continuously in the territory of Poland for between 1 and 10 years. Article 195 (4) of the Act on Foreigners sheds light that a stay is considered uninterrupted if none of the breaks therein was longer than 6 months and all breaks did not exceed a total of 10 months in the periods constituting the basis for granting permission for permanent residence, subject to some exceptions. ${ }^{73}$

Migrants in Poland need to file their permanent residence application in person, subject to some exceptions, no later than on the last day of their lawful stay in the territory of Poland.$^{74}$ They need to present, as part of the application, documentation justifying the granting of the permit such as information on foreign travel and any stays abroad that occurred within 5 years prior to filing the application and whether they were detained or sentenced to any period of imprisonment. ${ }^{75}$ The fee for initiating the procedure for a permanent residence permit is 640 PLN (151 EUR). ${ }^{76}$

By way of comparison, Article 25 of the Bulgarian Act on Foreigners contains provisions for accessing national permanent residence status. ${ }^{77}$ There are several categories of foreigners who can become eligible for this permit such as, inter alia,

\footnotetext{
${ }^{71}$ See Articles 8a-8d of the Act on Pole's Card, which were added by Act of 13 May 2016 amending the Act on the Pole's Card and certain other acts/Ustawa z dnia 13 maja 2016 r. o zmianie ustawy o Karcie Polaka oraz niektórych innych ustaw, (Dziennik Ustaw z 2016 r., poz. 753). This provision came into force on 1 January 2017.

${ }^{72}$ Article $195 \mathrm{AF}$.

${ }^{73}$ For instance, if the break was caused by performance of professional duties or performance of work outside the territory of the Republic of Poland on the basis of an agreement concluded with an employer whose office is located in Poland or a special personal situation required the presence of a foreigner outside the territory of Poland and lasted no longer than 6 months. For more details, see Article 195 (4) 1-4 AF.

${ }^{74}$ Article $202 \mathrm{AF}$.

${ }^{75}$ For detailed information on the required documents as part of the application, see Article $203 \mathrm{AF}$.

${ }^{76}$ MigrantInfo.pl (2019).

${ }^{77}$ Including also Articles 25 (a- г) AFRB.
} 
persons of Bulgarian origin, ${ }^{78}$ family members of Bulgarian citizens ${ }^{79}$ or family members of permanent residence permit holders ${ }^{80}$ investors,${ }^{81}$ and foreigners who have resided, legally and continuously, in the territory of Bulgaria for the last 5 years prior to applying for permanent residence and who have not been abroad for more than 30 months during this period. ${ }^{82}$ The latter is the only ground on which migrant workers could qualify for permanent residence, as according to the general admission framework, migrant workers need to leave the country after reaching the maximum permit validity of 3 years and reapply after a 3-month interruption between the expiration of their permit and the request for a new starting period of employment. ${ }^{83}$ The requirements for obtaining this permit differ depending on which category of person is applying for the status. For the purposes of this study, this section focuses only on the most relevant categories.

In line with Article 34 (1) of the Implementing Regulation of the Act on Foreigners, applicants for this type of permit need to provide evidence that they have stable, regular, foreseeable, and sufficient means of subsistence without resorting to the social assistance system. The amount of the subsistence must not be less than the minimum monthly salary or the minimum pension for the country. Furthermore, they must exhibit proof of accommodation and present a criminal record certificate from their country of origin or habitual residence, a copy of their passport, and a document confirming that they have paid the state fee of $1000 \mathrm{BGN}$ (500 EUR) ${ }^{84}$

Foreigners of Bulgarian origin who are applying for permanent residence need to fulfil all the conditions stipulated in Article 34 (1) of the Implementing Regulation of the AFRB except the subsistence requirement. ${ }^{85}$ They also need to present a birth certificate (Article 35 (1) of the Implementing Regulation of the AFRB). ${ }^{86}$ Foreigners who have resided legally and continuously in the territory of Bulgaria for the 5 years

\footnotetext{
${ }^{78}$ See Article 25 (1) 1 AFRB.

${ }^{79}$ See Article 25 (1) 4 and Article 25г AFRB.

${ }^{80}$ See Article 25 (1) 2 and 3 AFRB.

${ }^{81}$ Article 25 (1) 6, 7, 8, 13 and 16 AFRB.

${ }^{82}$ Article 25 (1) 5 . According to Article 25 a of the AFRB this permit can also be obtained by foreigners who have contributed to the Republic of Bulgaria in the public and economic sphere, in the sphere of national security, science, technology, culture, or sport, without having to fulfil the requirements of the AFRB.

${ }^{83}$ Chap. 6, Sect. 6.1.1.

${ }^{84}$ In accordance with Article 12 (1) of Tariff No 4 on the fees collected in the system of the Ministry of Interior under the State Fees Act/ Tарифа No 4 за таксите, които се събират в системата на Министерството на вътрешните работи по Закона за държавните такси (SG No. 27/10 March 1998, last amendment SG No. 75/11 September 2018).

${ }^{85}$ In case of such applicants, a notarised declaration by the owner to provide a residence address is required instead of a proof of accommodation.

${ }^{86}$ In the event that the applicant does not have a birth certificate, Ministry of Interior officials can substitute it with official information about the Bulgarian origin of the foreigner if the information is contained in an electronic system maintained by the State Agency for Bulgarians Abroad (Article 35 (2) of the Implementing Regulation of the AFRB).
} 
prior to submitting the application must also present the above-mentioned documents under Article 34 (1) of the Implementing Regulation of the AFRB. In order to be granted the permanent residence permit, the Ministry of Interior's Migration Directorate has to check its databases to confirm that the individual has legally and continuously resided in Bulgaria in the previous 5 years (Article 38a of the Implementing Regulation of the AFRB).

Finally, according to the bilateral labour migration agreements concluded by Bulgaria with Moldova and Armenia, workers are required to return to the territory of their sending state upon expiration of their legal residence and personally present their passport to its consulate within 1 month of their return (Article 23 of the Agreement of Moldova/Article 13 of the Agreement with Armenia). As already mentioned above, this means that they can stay for a maximum period of 3 years, after which they are obliged to leave the country and re-apply for another authorisation.

\subsubsection{Implementation Dynamics ${ }^{87}$}

According to the experts interviewed in Poland, migrants working on the basis of the Oświadczenie procedure did not usually face any problems in obtaining a work permit or a single permit with the same employer. ${ }^{88}$ One of the experts stressed that proof that this legal possibility was working well was the fact that in the last 2 years (2014-2016) Ukrainians who used to circulate on the basis of work visas, had begun changing their legal status to more stable single temporary permits, which then made them eligible to apply for an EU long-term or permanent residence. ${ }^{89}$ This 'massive growth in temporary permits' was mainly due to the political situation in Ukraine at the time. Most of the migrants, who wished to switch to a work or single permit, were fleeing from western Ukraine and sought to ensure that they would be allowed to stay in Poland if the conflict expanded. They were thus more willing to pay far greater fees for the temporary permits and go through the procedure, 'which is not as easy and nice as Oświadczenie', in order to secure a more stable status in Poland..$^{90}$

The study's focus group recruitment strategy did not aim to include migrants who were national permanent residence permit holders. Nevertheless, one of the Russian focus group participants who worked for a business corporation mentioned that she planned to apply for a permanent residence permit in the following year. ${ }^{91}$ According to her, the most important prerequisites for obtaining the permit were for

\footnotetext{
${ }^{87}$ For data on permits, see Chap. 6, Sect. 6.3.3.6.

${ }^{88}$ Interview \#12 with civil society actor, Poland, November 2016, Annex II.

${ }^{89}$ Interview \#12 with civil society actor, Poland, November 2016, Annex II.

${ }^{90}$ Interview \#12 with civil society actor, Poland, November 2016, Annex II.

${ }^{91}$ Focus group with Russian migrants, Poland, November 2016, Annex IV.
} 
the applicant to have a work contract, preferably a permanent one, as well as to demonstrate that the applicant had paid taxes in the previous years. She emphasised that her employer had offered her a permanent contract and paid all the requisite social security contributions, as well as private medical insurance. Her plan was to apply for permanent residence as a step towards gaining Polish citizenship, which would allow her to seek employment at EU institutions where she would receive a much better salary for the same position and tasks: 'That is why permanent residence permit and Polish citizenship is some kind of breakthrough to another level' ${ }^{92}$

As highlighted in Chap. $6,{ }^{93}$ most of the participants in the general focus groups entered Bulgaria by registering a trade representation and then seeking employment. Obtaining continuous residence on these grounds allowed them to accumulate uninterrupted periods of residence, which would then make them eligible for permanent or EU long-term residence. The challenges that they shared in this regard concerned the circumvention practices that they had to use in order to enter the country and stay, and the fact that it was too risky and too expensive to circulate on a voluntary basis since most of them wanted to stay in Bulgaria in any case.

\subsubsection{Residence Status According to EU Long-Term Residence Directive}

Foreigners who are not eligible for the Polish permanent residence procedure are able to rely on the EU long-term residence permit procedure. According to Article 211 of the Act on Foreigners, this permit is granted to foreigners at their request for an indefinite period of time, if they have been staying in Poland legally and uninterruptedly for a minimum of 5 years before applying and meet the following criteria: have a source of steady and regular income sufficient to cover subsistence costs for the sponsor and the dependent family members as well as health insurance ${ }^{94}$ or a document certifying that the costs of treatment in Poland will be covered by the insurer.

The income requirement is specified in Article 114 (2) of the AF stating that the monthly income shall be higher than the amount which would entitle a person to access cash benefits from the social assistance system, as specified in the Act of 12 March 2004 on Social Assistance ${ }^{95}$ with respect to the sponsor and each dependent family member. Foreigners must have maintained steady and regular income for

\footnotetext{
${ }^{92}$ Focus group with Russian migrants, Poland, November 2016, Annex IV.

${ }^{93}$ Sect. 6.2.

${ }^{94}$ Within the meaning of the Act of 27 August 2004 on health care service financed from public funds/ Ustawa z dnia 27 sierpnia 2004 r. o świadczeniach opieki zdrowotnej finansowanych ze środków publicznych, (Dziennik Ustaw z 2019 r., poz. 1373, consolidated text).

${ }^{95}$ Act of 12 March 2004 on Social Assistance/Ustawa z dnia 12 marca 2004 r. o pomocy społecznej (Dziennik Ustaw z 2019 r. poz. 1507, 1622, 1690, 1818, 2473, consolidated text).
} 
3 years of stay in Poland immediately before filing the application. ${ }^{96}$ With regards to Blue Card holders, however, only 2 years of stable income is required. ${ }^{97}$ This requirement for steady and regular income of 3 years can be considered disproportional based on the CJEU judgment in the case Khachab on the Family Reunification Directive, which can also be applied by way of analogy to the EU Long-term Residence Directive since the wording of the income requirement is almost identical in both directives. ${ }^{98}$

The amendments of the Polish Act on Foreigners, which entered into force on 12 February 2018, made migrants' access to EU long-term residence conditional on knowledge of the Polish language. ${ }^{99}$ According to Article 211 (3) of the Act on Foreigners, this can be evidenced through an official certificate of competency in the Polish language at least at the B1 level of language proficiency ${ }^{100}$ or an appropriate graduation certificate. ${ }^{101}$ Children under 16 are exempted from the language requirement. ${ }^{102}$

The 5-year period of stay in the territory of Poland includes the total period of legal stay in the EU for Blue Card holders, if they have resided in Poland for a minimum of 2 years immediately prior to filing the application ${ }^{103}$ or half of the period of legal stay in Poland in cases when they were residing on the basis of visas or temporary residence permits for the purposes of obtaining higher education or vocational training. ${ }^{104}$ The foreigners' stay, which is the grounds for granting them the EU long-term residence permit, is considered uninterrupted if none of the periods of absence were longer than 6 months and all the intervals were no longer than 10 months within the required 5-year period. ${ }^{105}$ In the case of Blue Card holders, the 5 -year period is considered uninterrupted if none of the periods of absence exceed 12 months or where all periods of absence were no longer than 18 months in total. ${ }^{106}$

\footnotetext{
${ }^{96}$ Article 211 (2) $2 \mathrm{AF}$.

${ }^{97}$ Article 211 (2) 1 AF.

${ }^{98}$ Case C-558/14, Khachab, ECLI:EU:C:2016:285, paras. 41-48.

${ }^{99}$ OECD (2018), p. 264. Currently in Article 211 (1) 3 AF.

${ }^{100}$ Referred to in Article 11a of the Act of 7 October 1999 on the Polish language/Ustawa z dnia 7 października 1999 r. o języku polskim (Dziennik Ustaw z 2019 r. poz. 1480, consolidated text).

${ }^{101}$ A certificate of completion of school in the Republic of Poland within the meaning of Article 2 (2) of the Act of 14 December 2016 on Education/Ustawa z dnia 14 grudnia 2016 r. - Prawo oświatowe (Dziennik Ustaw z 2019 r., poz. 1148, consolidated text) or higher education institutions within the meaning of the Act of 20 July 2018 on Higher Education and Science/Ustawa z dnia 20 lipca 2018 r. - Prawo o szkolnictwie wyższym i nauce (Dziennik Ustaw z 2018 poz. 1668) with Polish as the language of instruction; or a certificate of completion of a school or higher education institution with Polish as the language of instruction abroad, corresponding to the school or higher education institution within the meaning of Article 2(2) of the Act of 14 December 2016 on Education or the Act of 20 July 2018 on Higher Education and Science.

${ }^{102}$ Article 211 (4) AF.

${ }^{103}$ Article 212 (1) 1 AF.

${ }^{104}$ Article 212 (1) $3 \mathrm{AF}$.

${ }^{105}$ Article 212 (3) 1 AF.

${ }^{106}$ Article 212 (3) 2 AF.
} 
These rules do not apply, however, when the intervals were due to the performance of professional duties or work outside Poland under an agreement with an employer established on the territory of Poland; where family members accompanied a foreigner performing the abovementioned activities; in cases of exceptional personal situations requiring the foreigner's presence outside Poland for up to 6 months; or, for internships or classes provided for in the course of studies by a Polish university. ${ }^{107}$

Foreigners who have stayed legally and without interruption in the territory of Bulgaria for 5 years are also eligible to apply for the EU long-term residence permit in accordance with Article $24 \Gamma$ of the Act on Foreigners. In order to obtain such residence status, the applicants need to present: evidence that they have sufficient means of subsistence for themselves and their family members that is not less than the minimal salary or minimal pension, which would not require recourse to the social assistance system (Article 24г (9) of the AFRB). Furthermore, they must, as a matter of obligation, possess health insurance or insurance for the period of their stay in accordance with the applicable Bulgarian legislation.

For those who have resided exclusively on the basis of a temporary permit, such as au pairs, seasonal workers, cross-border service providers, posted workers for the purposes of cross border service provision, or where their residence permit is formally limited, they cannot have these periods of residence included in the calculation of the 5-year period (Article 24г (2) of the AFRB). EU Blue Card holders can be granted EU long-term residence status in Bulgaria if they have resided legally and uninterruptedly for a period of 5 years in a Member State as an EU Blue Card holder; two of the five last years must have been in the territory of Bulgaria (Article $33 \mathrm{M}$ (1) of the AFRB).

In accordance with Article $24 \Gamma$ (8) of the Bulgarian Act on Foreigners, periods of absence from the territory of Bulgaria do not interrupt the required 5-year period and can be included in the calculation, if they are less than six consecutive months and do not exceed a total of 10 months for the 5-year period. For Blue Card holders, the 5-year period is not to be considered interrupted by periods of absence from the territory of Bulgaria, if those periods are less than 12 consecutive months and the total duration does not exceed 18 months within the 5-year period. These periods of absence must be necessary for the exercise of an economic activity as either an employed or self-employed person; due to volunteer activity; or for education purposes in the Blue Card holder's country of origin (Article 33м (2) AFRB).

\subsubsection{Implementation Dynamics}

The migrants in Poland with high-skilled and low-skilled occupations shared different experiences regarding the process of obtaining an EU long-term residence permit. A Ukrainian having a high-skilled occupation who participated in the focus

${ }^{107}$ Article 212 (4) AF. 
group did not report any problems concerning the application process for the permit. ${ }^{108}$ What she complained about was the constantly evolving legislation, which made it very hard to make an informed decision. ${ }^{109}$

A Russian participant in the focus groups shared that he could not choose between the EU and the national permit because he did not have 'Polish roots' nor had he done 'anything outstanding for Poland'. Therefore, he had to apply for the EU long-term residence permit, and remarked that it was more difficult to obtain this permit. The focus group participant stressed that the governor examined his monthly income from the previous 3 years on the basis of the submitted tax return declaration $(P I T)$. His income could not be less than 468 złoty (110.50 EUR) per family member and at the beginning of the process his salary had been slightly less, which rendered him ineligible for the permit.

The Russian migrant worker said that the main problem with obtaining this permit was the dependency on the employer. For instance, if the employer did not pay the required taxes or social security contributions for the worker, even for a period of 2 months, this would cause the applicant to fail the permit procedure. However, in most cases, employers unlawfully demanded that migrants performing lowskilled jobs in restaurants or in the construction sector pay all social security contributions (ZUS) themselves. ${ }^{110}$ The respondent emphasised that he had been working and paying social security contributions on his own for 3 years and this is how he managed to obtain an EU long-term residence status. He added: 'If it is a lowskilled work, not in a corporation, employers won't hire you or you will be required to pay them back ZUS'.

The requirement for continuous employment (nieprzerwane zatrudnienie) was another hurdle for those wishing to obtain the EU long-term residence permit. ${ }^{111}$ If migrant workers became unemployed, they had to report this change in their status to the governor and were given only 1 month to find a new job. So, one could have worked for several years, striving to become eligible for an EU long-term residence permit, but if finding a new job took more than 1 month, one became unemployed and could not subsequently obtain this status. The respondent also stressed that the transposition of the Single Permit Directive had led to greater dependence on the employer due to the bureaucratic procedure for changing employment and that migrants who wished to apply for an EU long-term residence permit preferred to stay with the same employer rather than risk changing their permits and ending up with a period of unemployment. ${ }^{112}$

When the Russian participant in the focus group in Poland was asked whether he had circulated at any point during the 5-year period required for an EU long-term

\footnotetext{
${ }^{108}$ Focus group with Ukrainian migrants, Poland, November 2016, Annex IV.

${ }^{109}$ The participant referred to a period of more than 20 years since she was living in Poland.

${ }^{110}$ Migrants were paying the amount of social security contributions based on their income to employers who made the bank transfer and paperwork. Focus group with Russian migrants, Poland, November 2016, Annex IV.

${ }^{111}$ Focus group with Russian migrants, Poland, November 2016, Annex IV.

${ }^{112}$ See also Sect. 7.1.4.6 for more details.
} 
residence status, he said that he was aware of the limits to absence from Polish territory and therefore had deliberately remained in Poland for most of the time. ${ }^{113}$ Some of the interviewed Blue Card holders also shared this concern. Even though none of them were eligible to apply for an EU long-term residence permit at the time of the focus groups because they had only been in Poland for one-and-a-half or two years, most of them envisaged applying for this permit at some point in the future. According to the IT company management representatives, most of their employees were interested in obtaining an EU long-term residence permit in order to reduce the bureaucracy surrounding the renewal and extension of the Blue Card. ${ }^{114}$ Furthermore, from the management's perspective, it was more convenient if workers had a more permanent and stable status because this would allow them to travel and move with greater ease to different locations as the company's needs might require. Therefore, the IT company was investing in retaining the Blue Card holders in the country by offering free Polish language classes to the Blue Card holders and their spouses, support for spouses seeking a job, and introducing a simplified procedure for obtaining a mortgage.

By way of contrast, most migrant workers in Bulgaria had difficulties accessing an EU long-term residence status. The implementation of the Single Permit Directive created challenges for migrant workers, especially in relation to Bulgaria's migration policy focus of keeping migrants in a temporary position. As already mentioned, in accordance with Article 15 (3) of the ALMLM, the overall duration of the work authorisation can be prolonged by up to 3 years if the circumstances for its issue have not changed. After this period, the employee needs to leave the country. As one of the interviewed officials said:

'Then [after the three-year period] he has to leave. (...) Here the legislator for me quite consciously, has foreseen this interruption so that a period for permanent residence cannot be accumulated'. ${ }^{115}$

Indeed, this requirement interrupts the possibility for migrant workers to extend their continuous residence permit for another year, which needs to be submitted within 14 days before the permit is due to expire. Since migrant workers can have work authorisation for only up to 3 years, unless they are Blue Card holders or workers of Bulgarian origin, they do not have grounds for applying to extend their permit. Furthermore, they cannot change the grounds on which they entered Bulgaria from inside the country, and in any case need to leave if they would like to return to Bulgaria to work for the same employer or enter on a different basis. ${ }^{116}$ As already mentioned, this practice of 'forced circulation' creates obstacles for migrant workers in their transition to a permanent status and as a result forces them to

\footnotetext{
${ }^{113}$ Focus group with Russian migrants, Poland, November 2016, Annex IV.

${ }^{114}$ Interview with IT business management representative, Poland, December 2016, Annex II.

${ }^{115}$ Interview \#2 with official, Bulgaria, July 2016, Annex III.

${ }^{116} \mathrm{~A}$ proposal for amendment of the AFRB is pending at the time of finalisation of this text for publication. It could partially remedy this 'forced circularity' practice. See Draft Act on Amendments to the Act on Foreigners in the Republic of Bulgaria from 22 February 2020, Para 7 , Article 24и (3).
} 
undertake circumvention practices in order to find other ways to reside and settle in Bulgaria. Furthermore, as one of the interviewed lawyers said:

'And by doing all this, by throwing the worker out of here and sending him back to his country of origin, after all these costs he made, let's agree, that he would not come back here again. He will go somewhere where he does not have to do this thing. Not to mention that this demotivates people, because they do not know whether they will get a visa $\mathrm{D}$ or not (...) because the chances of not getting it are very big. (...) No worthy specialist with a worthy amount of money will subject himself to these administrative humiliations or obstacles to have the honour of working for Bulgaria'. ${ }^{117}$

According to IT business representatives, the 'forced circulation' practice that is inherent in Bulgarian migration law did not conform with the company's policy of retaining their employees. ${ }^{118}$ As stressed by one of the interviewees, the only privileged group of foreigners in Bulgaria were the Blue Card holders because they were not required to leave the country after their work authorisation period expired. However, the business representatives interviewed in 2016 stated that they were concerned whether this would be the case in practice because at the time of the interviews they did not have any Blue Card holders who had reached the threshold for permit renewal. ${ }^{119}$ The explicit grounds for extending the validity of the Blue Card permit for up to 4 years and its renewal within the country were only introduced in 2017 with the amendments to the Act on Foreigners. ${ }^{120}$

\subsection{Social Security Coordination ${ }^{121}$}

Circular migrants contribute at different times to the social security and health systems of two countries, raising the question of what happens with the contributions accumulated during the circulation period and after migrants decide to settle. The study's benchmarks in the field of social security coordination aim to assess what kinds of benefits can be exported and whether the general principles of social security coordination are covered: maintenance of the acquired rights and rights in course of acquisition; totalisation of periods of insurance, employment, or residence and of assimilated periods for the purpose of the acquisition, maintenance, or recovery of rights and for the calculation of benefits; and, equality of treatment. ${ }^{122}$ It also

\footnotetext{
${ }^{117}$ Interview \#9 with lawyer, Bulgaria, July 2016, Annex III.

${ }^{118}$ Interview \# 20 with IT business representatives, Bulgaria, December 2016, Annex III.

${ }^{119}$ Interview \# 20 with IT business representatives, Bulgaria, December 2016, Annex III.

${ }^{120}$ See Chap. 6, Sect. 6.3.3.1 for more details.

${ }^{121}$ This section builds on Vankova (2018),

${ }^{122}$ Based on, among others, Equality of Treatment (Social Security) Convention, C118, adopted at 46th ILC session on 28 June 1962, entry into force on 25 April 1964; Equality of Treatment (Accident Compensation) Convention, C019, adopted at 7th ILC session on 05 June 1925, entry into force on 8 September 1926. See Annex V for details. For more details, see Vankova (2016), p. 338.
} 
aims to assess whether reimbursement of social security contributions is possible ${ }^{123}$ and whether there are any instruments that support the implementation of these standards, such as multilateral and bilateral agreements.

\subsubsection{Social Security Coordination According to National Instruments in Poland and Bulgaria}

Poland has concluded bilateral social security agreements with a total of eight countries, two of which have been signed with Eastern Partnership countries - Ukraine and Moldova. ${ }^{124}$ Bulgaria, on the other hand, has concluded a total of 14 bilateral agreements. As in the case of Poland, two of the agreements were concluded with Eastern Partnership countries - Ukraine and Moldova. In addition, Bulgaria has also signed an agreement with Russia ${ }^{125}$ and at the time of writing was negotiating an agreement with Azerbaijan. ${ }^{126}$

The interviewed Polish ministry official shared that the agreements concluded by Poland were always based on the fundamental principles of coordination of social security systems contained in Regulation No. 883/2004: ${ }^{127}$ the principle of equal treatment; the principle of the export of benefits; and, the principle of the aggregation of insurance periods. ${ }^{128}$ By way of comparison, the Bulgarian institutions use the Model Provisions for a Bilateral Social Security Agreement contained in the European Convention on Social Security when they are beginning the negotiation of an agreement. ${ }^{129}$ Therefore the texts of the bilateral agreements concluded by both countries reflect all basic principles in social security coordination. ${ }^{130}$

Furthermore, as already mentioned, the Bulgarian government's policy is to conclude bilateral labour migration agreements with countries with which there is a social security coordination agreement or with which such an instrument is under

\footnotetext{
${ }^{123}$ In line with Article 27 (2) of ICRMW and Article 9 (1) of ILO Convention No. 143.

${ }^{124}$ The rest are with Yugoslavia (currently refers to: Bosnia and Herzegovina, Serbia and Montenegro), North Macedonia, Canada, USA, Republic of Korea, and Australia. It should be noted there is also an additional agreement with the Government of Quebec. For more details, see https://www.gov.pl/web/rodzina/dsz-wykaz-umow-o-zabezpieczeniu-spolecznym

${ }^{125}$ The rest are with Yugoslavia (currently refers to: Bosnia and Herzegovina), Serbia, Albania, Libya, Turkey, North Macedonia, Israel, Korea, Canada, Montenegro, and Tunisia.

${ }^{126}$ Interview \#4 with official, Bulgaria, July 2016, Annex III. See also official information on the website of the Bulgarian Ministry of Labour and Social policy. https://www.mlsp.government.bg/ index.php?section=CONTENT\&I=267 Accessed 30 September 2019. For the choice of countries, see Vankova (2018), p. 191.

${ }^{127}$ Regulation (EC) No 883/2004 of the European Parliament and of the Council of 29 April 2004 on the coordination of social security systems [2004] OJ L 166.

${ }^{128}$ Interview \#13 with official, Poland, December 2016, Annex II.

${ }^{129}$ Interview \#15 with official, Bulgaria, July 2016, Annex III.

${ }^{130}$ Vankova (2018), p. 194.
} 
negotiation. For instance, the bilateral labour migration agreement with Moldova is coupled with a social security agreement that was concluded in 2008 (see Article 12 of the Agreement with Moldova). ${ }^{131}$ In line with the Bulgarian policy on social security coordination, the bilateral labour migration agreement with Armenia provides that "until a bilateral social security agreement is concluded, the relevant legislation of the host party is applied' (Article 11). It should be stressed that Bulgaria primarily utilises the GAMM to initiate negotiations for the conclusion of bilateral social security coordination agreements. ${ }^{132}$

In most of the cases, the personal scope of the agreements between Poland and Bulgaria and the Eastern Partnership countries covers all persons who are or have been subject to the legislation of one or both contracting parties, as well as other persons who derive rights from such persons. The agreements between Bulgaria and Russia $^{133}$ and Bulgaria and Ukraine, ${ }^{134}$ however, have a very limited personal scope and concern, respectively, only Russian, Ukrainian, and Bulgarian citizens.

The material scope of the two agreements with Poland cover old-age pensions, disability pensions, pensions in respect of accident at work and occupational diseases, and survivors' pensions, which are also exportable benefits. ${ }^{135}$ In addition, the agreement between Ukraine and Poland has broader material scope that includes unemployment benefits, maternity and paternity benefits, sickness cash benefits, and death grants. ${ }^{136}$ This agreement allows for export of maternity and paternity benefits and sickness cash benefits. ${ }^{137}$

Most of the social security agreements that Bulgaria has concluded with Eastern Partnership countries exclude family benefits and healthcare benefits. The agreements concluded with Ukraine, Moldova, and Russia cover sickness cash benefits, including maternity benefits, old-age pensions, disability pensions, pensions in respect of accident at work and occupational diseases, survivors' pensions, and death grants. In addition, the agreements with Moldova and Ukraine include unemployment benefits in their material scope, while the agreement with Russia includes family benefits. The agreements with Eastern Partnership countries that Bulgaria has concluded cover mainly export of pensions. ${ }^{138}$

\footnotetext{
${ }^{131}$ Agreement between the Republic of Bulgaria and the Republic of Moldova on social security, signed on 5 December 2008, in force since 1 September 2009/Договор между Република България и Република Молдова за социално осигуряване, подписан на 5 декември 2008 г., в сила от 1 септември 2009 г.

${ }^{132}$ Interview \#1 with official, Bulgaria, July 2016, Annex.

${ }^{133}$ Article 3.

${ }^{134}$ See Article 3, Article (1) 1 paragraphs 4 and 6.

${ }^{135}$ Agreement between the Republic of Poland and the Republic of Moldova on Social Insurance, Article 2 and Article 5. Agreement between the Republic of Poland and the Republic of Ukraine on social security, Article 2 and Article 5.

${ }^{136}$ Article 2 of the Agreement.

${ }^{137}$ See European Migration Network (2014a).

${ }^{138}$ For more details see, European Migration Network (2014b).
} 
According to Article 132 of the Polish Act of 17 December 1998 on Old-Age and Disability Pensions from the Social Insurance Fund, ${ }^{139}$ even when there is no bilateral social security agreement with a particular third country, the payment of old-age and disability pensions is still possible in Poland: 'At the request of a retiree or pensioner living abroad the pension shall be received by a person authorised to receive the pension, who is domiciled in Poland or into the account of the retiree or pensioner in his/ her country, unless international treaties provide otherwise'. ${ }^{140}$ In practice this means that Polish pensions are exported to the pensioner's state of residence only if Poland has a bilateral social security agreement with that state. However, when there is no such agreement, the pensions can be paid in Poland to a person authorised by the pensioner and who resides in Poland, or to the pensioner's bank account in Poland. In cases where there is no bilateral social security agreement between Bulgaria and a third country, the Bulgarian Ordinance on Pensions and Insurance Periods ${ }^{141}$ does not provide for the payment of pensions abroad, which was also stressed by the European Commission in its Implementation report on the Single Permit Directive. ${ }^{142}$ Yet, according to one interviewed official, in practice pensions are transferred via the post office and the pensioners' bank accounts. ${ }^{143}$ Thus, the person can live abroad and receive a Bulgarian pension as long as they retain a bank account in Bulgaria.

Finally, there are no legal provisions in Bulgarian or Polish social security law or any of the concluded bilateral social security agreements with the Eastern Partnership countries in question stipulating the possibility for social security contributions to be reimbursed when these are not accessible to the migrants.

\subsubsection{Implementation Dynamics ${ }^{144}$}

The data on the exported Polish pensions to Ukraine and Moldova demonstrates the marginal use of these agreements, especially when one compares them to the number of migrants working in Poland ${ }^{145}$ or the number of foreigners registered as insured for pension at the Polish Social Security Institution. ${ }^{146}$ The number of

\footnotetext{
${ }^{139}$ Ustawa z dnia 17 grudnia 1998 r. o emeryturach i rentach z Funduszu Ubezpieczeń Społecznych, (Dziennik Ustaw z 2018, poz. 1270, consolidated text).

${ }^{140}$ Interview \#13 with official, Poland, December 2016, Annex II.

${ }^{141}$ Наредба за пенсиите и осигурителния стаж, (SG No. 21/17 March 2000, last amendment SG No. 62/6 August 2019)

${ }^{142}$ European Commission (2019), pp. 10-11.

${ }^{143}$ Interview \#15 with official, Bulgaria, July 2016, Annex III.

${ }^{144}$ This section builds on Vankova (2018).

${ }^{145}$ See Chap. 6, Sect. 6.2.

${ }^{146}$ In 2018, there were 425,670 Ukrainians and 7337 Moldovans registered in ZUS. Data from Departament statystyki i prognoz aktuarialnych, Cudzoziemcy w polskim systemie ubezpieczeń społecznych, Warszawa 2019. https://www.zus.pl/documents/10182/2322024/Cudzoziemcy+w+p olskim+systemie+ubezpiecze \% C5\% 84+spo\% C5\% 82 ecznych.pdf/4498fca6-981da37c-3742-8e4e74e20a32\#page =8 Accessed 19 November 2019.
} 


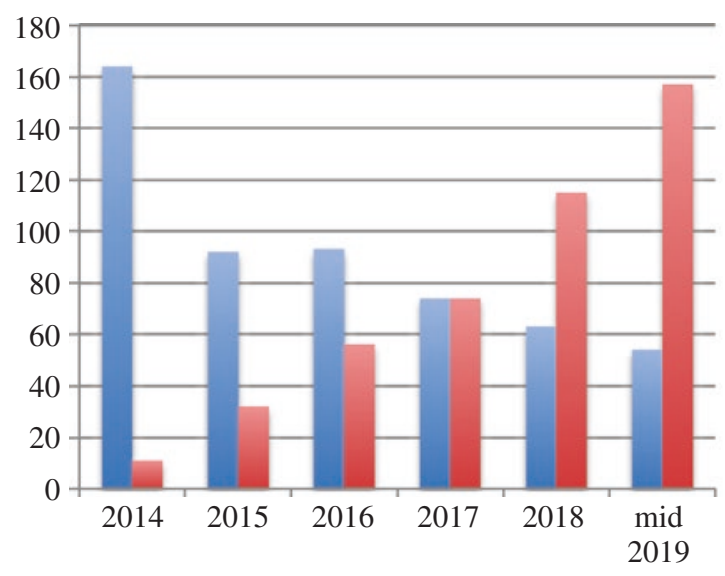

Number of applications for foreign pensions

Average month number of persons who have transferred Polish pensions according to the social security agreement

Fig. 7.1 Data on the implementation of the social security agreement between Poland and Ukraine. Source: Author's own elaboration on the basis of data of the Ministry of Family, Labour and Social Policy, Poland. (Data retrieved from an interviewed official at the Ministry of Labour and Social Policy, Poland, 7 August 2019)

persons who have transferred Polish pensions under the social security agreement with Ukraine (on the basis of a monthly average), doubled between 2017 and mid-2019, reaching a total of 157 persons in mid-2019. In addition, only five people had transferred their pensions to Moldova by mid-2019.147 (Figs. 7.1 and 7.2).

Even though the data obtained from the Bulgarian and Polish institutions differs and cannot be directly compared, it still offers a good insight into the implementation dynamics of the social security agreements with the Eastern Partnership countries and Russia. As of mid-2019, 50 Bulgarian pensions were transferred to Ukraine on the basis of the bilateral agreement to Bulgarians who had worked both in Bulgaria and Ukraine (see Fig. 7.3). ${ }^{148}$ On the other hand, 936 Ukrainian pensions were being paid in Bulgaria in the same reporting period. As Fig. 7.5 demonstrates, the implementation of the agreement between Moldova and Bulgaria is insignificant.

Against this background, the implementation dynamics of the agreement between Russia and Bulgaria differs drastically. The number of Russian pensions that are paid in Bulgaria as of mid-2019 is 5451 and the figure for Bulgarian pensions paid in Russia is 185 (see Fig. 7.4). One interviewed official said that in both cases the beneficiaries were mainly Russian citizens. ${ }^{149}$ In addition, the interviewee shared that it was quite challenging to keep the data up to date because new pensioners were added or removed from the lists every month due to deaths that took place.

\footnotetext{
${ }^{147}$ Interview \#13 with official, Poland, December 2016, Annex II.

${ }^{148}$ Data obtained from the National Social Security Institute in August 2019.

${ }^{149}$ Ibid.
} 
7 Implementation of National Approaches to Circular Migration: Work Authorisation...

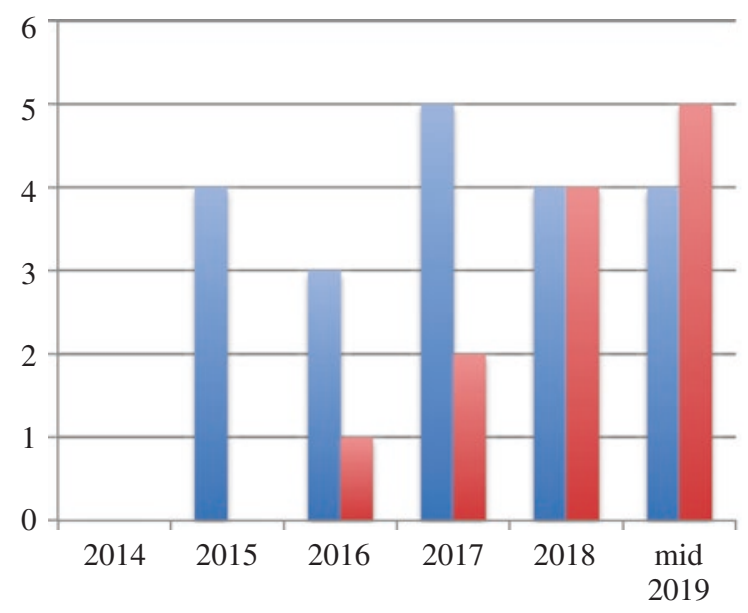

Number of applications for foreign pensions

= Average month number of persons who have transferred Polish pensions according to the social security agreement

Fig. 7.2 Data on the implementation of the social security agreement between Poland and Moldova. Source: Author's own elaboration on the basis of data of the Ministry of Family, Labour and Social Policy, Poland

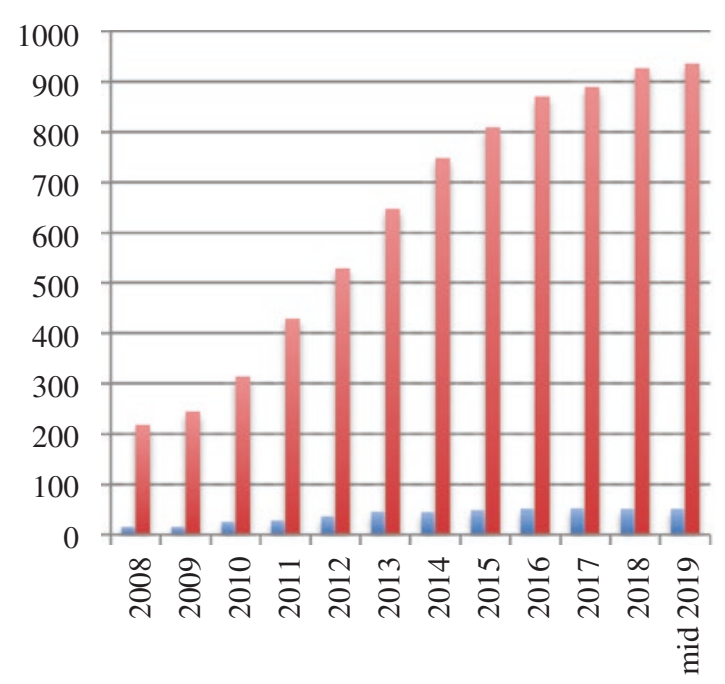

Bulgarians receiving their pensions in Ukraine

Ukrainians receiving their pensions in Bulgaria

Fig. 7.3 Data on the implementation of the social security agreement between Bulgaria and Ukraine. Source: Author's own elaboration on the basis of data of the National Social Security Institute, Bulgaria 


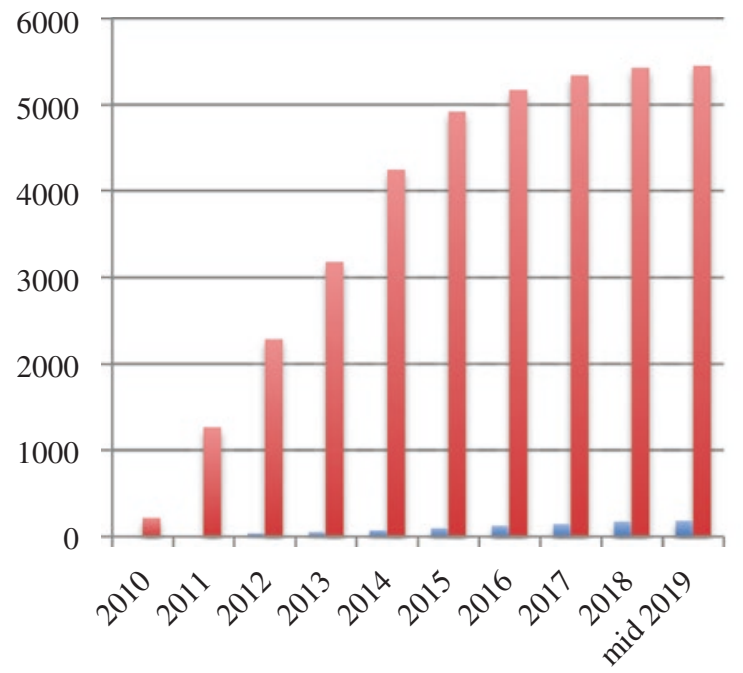

Bulgarians receiving their pensions in Russia

- Russians receiving their pensions in Bulgaria

Fig. 7.4 Data on the implementation of the social security agreement between Bulgaria and Russia. Source: Author's own elaboration on the basis of data of the National Social Security Institute, Bulgaria



Bulgarians receiving their pensions in Moldova

- Moldovians receiving their pensions in Bulgaria

Fig. 7.5 Data on the implementation of the social security agreement between Bulgaria and Moldova. Source: Author's own elaboration on the basis of data of the National Social Security Institute, Bulgaria 
The results from the conducted focus groups with migrants in Poland and Bulgaria showed that the levels of awareness about the existence and aims of the bilateral social security agreements are very low. Only two Ukrainian participants from the two general focus groups and two of the Blue Card holders interviewed in Poland knew something on this subject. ${ }^{150}$ One of the Ukrainians had informed himself through a TV programme. The other participant in the focus group shared the experience of her mother who retired in Ukraine after working in Poland for 10 years; the years that the mother had worked in Poland were counted as a basis for her pension in Ukraine. The focus group participant was surprised by this positive development:

'That's really strange because the ZUS (Zakład Ubezpieczeń Społecznych, Social Security
Institution) in Poland is all mess and, as far as I know, they are even unable to calculate
pensions transparently for Poles, let alone for Ukrainians. In the Ukraine, for its part, I can
tell you from my experience that the institutions are also stubborn in accepting documenta-
tion proving that you worked ten years in Poland and count this experience as a basis to
obtain pension in the Ukraine'.

One of the interviewed lawyers from an NGO shared that since the conclusion of the agreement with Ukraine, they had very few social security cases and when they did, these mostly concerned problems with migrant workers who wanted to retire and were having trouble collecting all the documents needed to be able to benefit from the provisions of the bilateral agreement. ${ }^{151}$

Most of the Blue Card holders who participated in the focus groups in Poland mentioned that they were not interested in this issue because the pensions that they would get from both Poland and Russia were extremely low (250 EUR in Poland and 170 EUR in Russia).

In the focus group with Ukrainian migrants in Bulgaria, there were only two retired participants who knew about the agreement between Bulgaria and Ukraine. ${ }^{152}$ One of them was a circular migrant during the communist regime who had started receiving a disability pension when she was still in Ukraine. Four months after she moved to Bulgaria in 1988, she began to receive her disability pension under the former agreement that was in operation between the country and the Soviet Union. The second participant was actively engaged with the Ukrainian community in Bulgaria and she shared that Ukrainian women who married Bulgarians and moved to Bulgaria after they had worked in Ukraine did not generally face any problems with the export and calculation of their pensions on the basis of the existing agreement. She had been aware of how to proceed when she had decided to retire in Bulgaria.

\footnotetext{
${ }^{150}$ Focus groups with Russian migrants and Ukrainian migrants, Poland, November 2016, Annex IV. Focus group with Blue Card holders from Ukraine, Poland, December 2016, Annex IV. Focus group with Blue Card holders from Russia, Poland, December 2016, Annex IV.

${ }^{151}$ Interview \#13 with civil society actor, Poland, November 2016, Annex II.

${ }^{152}$ Focus groups with Ukrainian migrants, Sofia, September 2016, Annex IV.
} 
There was only one pensioner in the focus groups conducted with Russian migrants. ${ }^{153}$ She knew about the bilateral social security agreement between Russia and Bulgaria, and said that she received pensions from both countries and that she preferred to receive the Russian pension in a Russian bank because she often travelled to Russia to visit friends and family.

In Bulgaria, only two Blue Card holders who participated in the focus group with Russians knew that there was an agreement between Bulgaria and Russia. ${ }^{154}$ They would only associate this agreement with the payment of pensions, something that was not currently on their agenda. They did not know the details of this agreement, however. Their main concern was access to healthcare. As migrants, they were entitled to medical aid only in emergency cases, and this was funded by the state budget. ${ }^{155}$ Apart from that, unless they held EU long-term residence or permanent residence permits, they could not use the healthcare provided by the state, benefit from the Blue Card Directive or the bilateral social security agreement between Bulgaria and Russia because this was not part of the material scope of these instruments. Therefore, they all used private health insurance.

The focus group data show that mainly people who were retired or had retired relatives were aware of the existence of the concluded bilateral social security agreements. One of the factors contributing to the low awareness among the interviewed Blue Card holders was the fact that they had moved to Poland and Bulgaria relatively recently, on average between one-and-a-half and two years before the interviews were conducted. In addition, many were young people at the beginning of their careers. Finally, most of the Russian Blue Card holders did not want to return to Russia and some stressed that they did not want to have anything to do with the Russian authorities.

\subsection{Conclusion}

When Poland and Bulgaria's circular migration approaches are analysed and compared beyond entry and re-entry conditions for migrants, the implementation picture of the EU's approach to facilitating this type of migration becomes even more nuanced. This chapter focused on instruments considered conducive to circular migration and aimed to assess them against the study's benchmarks developed in the areas of work authorisation, residence status, and social security coordination (see Annex V).

In the field of work authorisation, Poland facilitates circular migration through both national and EU instruments. The national instruments differ in their scope insofar as they explicitly allow for a change of employer and occupation, as well as

\footnotetext{
${ }^{153}$ Focus groups with Russian migrants, Sofia, September 2016, Annex IV.

${ }^{154}$ Focus group with Blue Card holders from Russia, Bulgaria, September 2016, Annex IV.

${ }^{155}$ European Migration Network (2014b), p. 22. See also Huddleston et al. (2015).
} 
the implications of unemployment on the permit status. In the Bulgarian case, however, the national regime does not contain any of the international standards employed as benchmarks of this study. Unemployment is treated as a change in migrant workers' admission grounds and leads to 'forced circularity'. The only exceptions are those introduced through EU law and for foreigners of Bulgarian origin.

Furthermore, the empirical data analysis suggests certain problems with regards to the protection of migrants' rights in both countries. In Poland this is mainly in the context of the Oświadczenie procedure, which despite the recent reforms still creates legal uncertainty and insufficient enforcement when it comes to obtaining employment contracts and thus places migrant workers in a vulnerable position. In Bulgaria, the 'forced circulation' logic, combined with the lack of flexible solutions to change employer and occupation as well as the risk of becoming unemployed, essentially binds migrant workers to their employers.

While transposing the EU labour migration acquis, both countries have established bureaucratic and cumbersome procedures, which in most cases lead to impractical solutions. For instance, the implementation of the Single Permit Directive in Poland has led to workers being bound to their employer because the transposition into Polish law has made it extremely difficult for those workers to change employer or occupation. The transposition of EU labour migration law in Bulgaria, however, is the only way through which standards in this field can become embedded in the Bulgarian legal order. Thus, it is currently only Blue Card holders and seasonal work permit holders who, on the basis of EU law, can benefit from the right to change employer. Blue Card holders can also stay in the country if they become unemployed. Neither Poland nor Bulgaria have adopted measures that allow researchers to change employer nor do they provide the possibility for researchers to find another job if they become unemployed.

When it comes to access to a more settled residence status, both case studies demonstrate that, in general, circular migration and the accumulation of continuous residence periods, which in most cases are needed in order to obtain an EU longterm residence or permanent residence status, are mutually exclusive. Migrant workers who are engaged in circulation need to either change their migration trajectory or utilise the limited permitted absences available under the EU and national permits. The empirical data analysis demonstrates that migrants who have decided to obtain an EU long-term or permanent residence status prefer not to engage in circulation for work purposes because this is perceived as being too risky.

The two case studies, however, differ regarding access to permits that allow their holders to transition from a temporary to a more permanent status. The Polish model provides some flexibility for circular migrants to transit to a single permit. However, the analysis of the implementation data in Poland highlighted a problem with the secondary transition from a single permit to a permanent or an EU long-term residence permit. The increasingly demanding requirements imposed as a result of the transposition of the EU Long-term Residence Directive into Polish law, as well as the cumbersome procedure for its implementation, make it very difficult to actually access this type of permit, especially for migrants in low-skilled occupations. Migrants shared that the main challenges while on a single permit were related to 
their dependency on employers - who very often required migrants in low-skilled occupations to pay their own social security contributions - as well as to the requirement for continuous employment.

By way of contrast, generally migrant workers in Bulgaria cannot transfer from one status to another, at least not while they are in the country. Furthermore, Bulgarian migration law, which establishes a practice of 'forced circulation', currently renders access to permanent residence status challenging and to EU longterm residence practically impossible for migrant workers, except for foreigners who can prove that they are Blue Card holders. This is not in line with the international standards deployed by the current study as benchmarks (see Annex V). Therefore, the circumvention practices that were documented in Bulgaria (e.g., registration of trade representation) in many cases are the only means for migrant workers to access a more secure status in Bulgaria.

In both countries, access to permanent residence status is facilitated only for certain privileged groups of migrants, which both countries try to attract based on their ethnic origin. In addition, all the instruments analysed allowed for free movement and a choice of residence within Bulgaria and Poland. None of the interviewed migrants reported any problems in this regard.

Finally, when it comes to social security coordination, this chapter has demonstrated that the bilateral agreements concluded by both Bulgaria and Poland with the Eastern Partnership countries cover all the basic social security coordination principles that served as benchmarks in this study. However, neither country has legislated for the reimbursement of social security contributions in cases where migrants and their families cannot access benefits due to waiting periods in the host country or the lack of a bilateral agreement that provides for the export of benefits. This is a provision contained in Article 27 (2) of the Convention on the Protection of the Rights of all Migrant Workers and the Members of Their Family. This standard should be especially considered in the context of the short-term circular migration of seasonal workers. ${ }^{156}$

With regards to their material scope, all agreements between Bulgaria and Poland and the Eastern Partnership cover pensions - old age, disability pensions, pensions in respect of accidents at work and occupational diseases, and survivors' pensions. Apart from this, the agreements with the different countries vary in other areas. Family benefits, for instance, are covered only in the agreement between Russia and Bulgaria. In addition, it seems that unemployment benefits are an important issue for Ukraine because it is foreseen in the bilateral agreements with both Poland and Bulgaria. Shedding more light on the reasons for that, however, would require additional field research covering interviews with delegation members who were part of the negotiations of these agreements.

The agreements between Bulgaria and Russia and Bulgaria and Ukraine demonstrate another potential source of vulnerability for circular migrants. Both have a very narrow personal scope insofar as they cover only nationals of the contracting

\footnotetext{
${ }^{156} \mathrm{~A}$ recommendation in this regard is also expressed by Verschueren (2016), p. 407.
} 
parties and can exclude third-country nationals from benefiting from the provisions of the bilateral agreements and create additional gaps in a field that is already plagued with inconsistencies.

This study has demonstrated that the number of bilateral agreements, which are the main instruments used in the field of social security coordination, is low despite the cultural, historical, and geographic proximity of Bulgaria and Poland with the countries in the Eastern Partnership. It seems that the policy channels provided by the GAMM do not do enough to facilitate the process of starting negotiations with these countries, even though Bulgaria is actively using it.

Another problem that has been identified in both countries pertains to the implementation of these instruments. The lack of awareness among the migrants interviewed, as well as the low number of beneficiaries of the agreements, especially in the case of Poland, means that there is a need for an active information policy on these issues, which are technical and not easily understandable to migrants who do not necessarily have a good knowledge of the local language. Migrants need to be actively informed about their rights during their period of circulation. Waiting until the age of retirement could lead to the loss of entitlement or problems created by the lack of documents that need to be presented to the respective social security institution.

\section{References}

Deloitte. (2018). ICT Permit Study. Facilitating EU Mobility for Third-country Nationals, June 2018. https://www2.deloitte.com/content/dam/Deloitte/global/Documents/Tax/dttl-tax-ictpermit-study.pdf Accessed 19 December 2019.

European Commission. (2019). Report on Directive 2011/98/EU of the European Parliament and of the Council of 13 December 2011 on a single application procedure for a single permit for third-country nationals to reside and work in the territory of a Member State and on a common set of rights for third-country workers legally residing in a Member State, COM (2019) 160 final, 29 March 2019, Brussels.

European Migration Network. (2012). Visa policy as migration channel in Poland. National Report. Prepared by the National Contact Point to the European Migration Network, Warsaw.

European Migration Network. (2014a). Migrant access to social security in Poland. Report produced by National Contact Point to the European Migration Network in Poland, Warsaw. https://ec.europa.eu/home-affairs/sites/homeaffairs/files/what-we-do/networks/european migration_network/reports/docs/emn-studies/21a_poland_national_report_social_security_ en.pdf Accessed 19 April 2020.

European Migration Network. (2014b). Migrant access to social security and healthcare: policies and practice in Bulgaria. Ministry of Interior. https://ec.europa.eu/home-affairs/sites/homeaffairs/files/what-we-do/networks/european_migration_network/reports/docs/emn-studies/ illegally-resident/03.bulgaria_national_report_social_security_en_version.pdf Accessed 19 April 2020.

Executive Agency Main Labour Inspectorate. (2019). Activity Report of the Executive Agency Main Labour Inspectorate in 2018, June 2019, Sofia.

Home Office. (2016). Country policy and information note. Ukraine: Military Service. Version 3.0, November 2016. https://www.refworld.org/pdfid/5890825c4.pdf Accessed 29 April 2020. 
Huddleston, T., Bilgili, Ö., Joki, A., \& Vankova, Z. (2015). Migrant Integration Policy Index (MIPEX). CIDOB and MPG, Brussels/Barcelona. http://www.mipex.eu/bulgaria Accessed 15 May 2015.

MigrantInfo.pl. (2019). Permanent residence permit. http://www.migrant.info.pl/permanent-residence-permit.html Accessed 19 December 2019.

OECD. (2018). International immigration outlook 2018: Poland. Paris: OECD Publishing.

Pawlak, M. and I. Lashchuk. (forthcoming). Entry to the labour market, not to the state - migrant workers' perspectives in Poland. Report commissioned by the Friedrich Ebert Foundation.

Skeldon, R. (2012). Going round in circles: Circular migration, poverty alleviation and marginality. International Migration, 50(3), 43-60.

Unterschütz, J. (2016). National report on implementation of EU migration directives in Poland. In R. Blanpain, F. Hendrickx, \& P. Olsson (Eds.), National effects of the implementation of EU directives on labour migration from third countries (pp. 161-192). Alphen aan den Rijn: Wolters Kluwer.

Vankova, Z. (2016). EU circular migration policies: Dead or alive? Developing a rights-based benchmark framework for policy assessment. Journal of Immigration, Asylum and Nationality Law, 30(4), 332-352.

Vankova, Z. (2018). Poland and Bulgaria's bilateral agreements with Eastern partnership countries in the context of circular migration. European Journal of Social Security, 20(2), 188-203.

Vankova, Z. and B. Ivanova (forthcoming) Temporary home or final destination? Migrant workers' perspectives in Bulgaria. Report commissioned by the Friedrich Ebert Foundation.

Verschueren, H. (2016). Employment and social security rights of third-country labour migrants under EU law: An incomplete patchwork of legal protection. European Journal of Migration and Law, 18(4), 373-408.

Open Access This chapter is licensed under the terms of the Creative Commons Attribution 4.0 International License (http://creativecommons.org/licenses/by/4.0/), which permits use, sharing, adaptation, distribution and reproduction in any medium or format, as long as you give appropriate credit to the original author(s) and the source, provide a link to the Creative Commons license and indicate if changes were made.

The images or other third party material in this chapter are included in the chapter's Creative Commons license, unless indicated otherwise in a credit line to the material. If material is not included in the chapter's Creative Commons license and your intended use is not permitted by statutory regulation or exceeds the permitted use, you will need to obtain permission directly from the copyright holder.



